\title{
Quantitative Determination of PCR Products by Colorimetric Method
} Jaime A. Dayanghirang ${ }^{1,2)}$ and Masanori Matsuoka ${ }^{1)}$

(1) National Institute for Leprosy Research, Tokyo, Japan

2) Dr. Jose N. Rodriguez Memorial Hospital, Tala, Caloocan City, Philippines)

(Received for publication : September 4, 1992)

Key words: PCR, Quantitative estimation, Non-radioactive probe, ELISA

\section{INTRODUCTION}

Leprosy is a chronic infectious disease which still exists as a major health problem in developing countries. Early detection of the disease is essential for efficient treatment for the patient and several diagnostic tools are currently available for this purpose. One of the molecular biological techniques, which is named polymerase chain reaction (PCR), can theoretically detect one bacillus or the single copy of gene in a sample preparation by enormous amplification of target sequence ${ }^{1)}$. The amplification of Mycobacterium leprae DNA by PCR has gained popularity among leprosy researches due to its high degree of specificity and sensitivity. Applications of PCR for $M$. leprae had been reported in several publications 2.3 .4 .5 .6 .7$)$ and expected to be highly potential for the detection of leprosy bacilli from clinical materials.

PCR studies sometimes require quantitative determination of amplified DNA to know the original DNA concentration or original bacillary number in the reaction mixture subsequently. Agarose gel staining, ultra-violet (U. V.) spectrophotometry and hybridization with radioactively labeled probe are some of the established methods to determine DNA quantitatively. However, each of them has its own drawbacks for the purpose mentioned above. The intensity of the band in agarose gel staining is proportional to the amount of original template and amplified DNA segment : that is, the template DNA from higher bacillary number produces a more intense band than those of lower bacillary number. However, this method is quite subjective and not enough sensitive, so it does not reflect the true DNA concentration. It is also possible to analyze quantitatively by spectrophoto meter. This procedure is not applied in PCR, because U. V. is absorbed by amplified DNA, also by free primers and dNTP's which tend to give false positive results. The use of isotope probe is hazardous and not practical for routine work.

Experimental procedure reported here is an innovation to estimate the quantity of amplified PCR products with high sensitivity and accuracy using non-radioactive probe suggested by Inouye et al. ${ }^{81}$. The technique involved four steps ; denaturation and adsorption of DNA to the plate, probe hybridization, antibody binding, and the usual color development as in ELISA.

\section{MATERIALS AND METHODS}

\section{PREPARATION OF DNA AS A STANDARD}

$M$. leprae Thai-53 strain was harvested from the footpad of nude mice, centrifuged at $200 \times \mathrm{g}$ for ten minutes and at $6,000 \times \mathrm{g}$ for twenty minutes, was resuspended in phosphate buffered saline (PBS ; 10 mM, pH 7.2). Bacillary number was adjusted to 4.0 
Jaime, A. Dayanghirang - Masanori, Matsuoka

$\times 10^{8} / \mathrm{ml}$. DNA was prepared according to Wood's method $^{3)}$; in brief, tubes containing bacterial material were boiled for five minutes and then rapidly freezed at $80^{\circ} \mathrm{C}$ for twenty minutes. This procedure was repeated for four times. The PCR primers $18 \mathrm{~F}$ and $18 \mathrm{R}$, coding a 360 bps of $18-\mathrm{KD}$ protein of $M$. leprae, were used. Primer $18 \mathrm{~F}$ spans from position 718 to 741 , while primer $18 \mathrm{R}$ covers 1078 to $1054^{5.9)}$. Tubes containing $100 \mu \mathrm{I}$ of reaction mixture, according to the manufacture's specification on Taq polymerase (Perkin-Elmer Cetus), were incubated for 30 cycles using the following conditions to amplify the DNA as standard; denaturation at $94^{\circ} \mathrm{C}$ for 90 seconds, annealing at $50^{\circ} \mathrm{C}$ for two minutes, extension at $72^{\circ} \mathrm{C}$ for two minutes. The amplification of DNA as desired size was confirmed by agarose gel electrophoresis. The DNA was treated with phenol: chloroform and precipitated with ethanol. The material was resuspended in TE buffer $(10 \mathrm{mM}$ Tris/HCl, $1 \mathrm{mM}$-EDTA, $\mathrm{pH}$ 8). Purified material was filtered using Suprec-02 Ultra filter (Takara) to remove excess free primers and dNTP's. The concentration of the purified and filtered materials were analyzed by spectrophotometer at $260 \mathrm{~nm}$.

\section{Preparation of probe}

Non-radioactive biotin and digoxigenin labeled probe were prepared by the PCR. The dilution of 1 : 1,000 (approximately $40 \mathrm{ng} / \mathrm{ml}$ ) of the previously purified and filtered PCR products were used as template. Concentration of labeled dUTP in dNTP's mixture was adjusted according to the formula preparing the probe from double stranded sequence using random primer and Klenow fragment (Boehringer Mannheim). The dUTP labeled with biotin (Enzo Biochem. . Inc.) or digoxigenin

(Boehringer Mannheim) were added to dNTP mixture $(70 \mu \mathrm{M})$. Final concentration of dGTP. dCTP, and dATP was $200 \mu \mathrm{M}$ each and that of dTTP was $130 \mu \mathrm{M}$. PCR was done using the same primers and cycling conditions as mentioned above. The integration of labeled dUTP was certified by agarose gel electrophoresis and color dcvelopment in the micro-plate. The amplified probe was purified by phenol : chloroform extraction, and resuspended in $100 \mu 1$ of TE buffer. Concentration of labeled probes were adjusted to $16 \mathrm{ng} / \mu \mathrm{l}$ and stored until use.

\section{Hybridization procedures}

DNA was denatured by boiling for 5 minutes followed by snap chilling, and was diluted by serial two-fold dilution with adsorbing buffer $(1.5 \mathrm{M}$ $\mathrm{NaCl}, 10 \mathrm{mM} \mathrm{Na} 2 \mathrm{HPO}_{4}, 10 \mathrm{mM} \mathrm{EDTA}$ ) according to Inouye's method (8). Samples in $100 \mu \mathrm{l}$ of the buffer were adsorbed into NUNC.Immunoplate Maxisorp F96 (Inter Med) by incubation for two hours at $37^{\circ} \mathrm{C}$, followed by washing with PBS. Tween (PBS cotaining $0.5 \%$ of Tween-20). After drying the plates for two hours at $42^{\circ} \mathrm{C}$, the digoxigenin and biotin probe were denatured and diluted $1: 2,000$ with mixture of equal volume of adsorbing buffer and formamide containing $0.1 \%$ Tween 20 and $50 \mu \mathrm{g} / \mathrm{ml}$ of heat denatured salmon sperm. Plates were sealed tightly after $100 \mu$ of diluted probe was added, and incubated overnight at $42^{\circ} \mathrm{C}$ in water bath. The plate treated with digoxigenin-11-dUTP probe was washed with $10 \mathrm{mM}$ PBS, and blocked with $5 \%$ skim milk in the PBS for one hour at $37^{\circ} \mathrm{C}$. Fifty $\mu l$ of diluted anti-digoxigenin antibody conjugated with peroxidase (Boehringer Mannheim) diluted 1:2,000 with PBS was added, and incubated for one hour at $37^{\circ} \mathrm{C}$. Biotin treated plate was incubated for one hour at room temperature after addition of $50 \mu \mathrm{L}$ of streptavidin-peroxidase conjugate (GIBCO BRL) diluted 1:1,000 with PBS. Fifty $\mu$ l of the mixture of $\mathrm{H}_{2} \mathrm{O}_{2}$ and $\mathrm{O}$-phenylenediamine in citrate buffer were added to each well, and kept for 30 minutes in the dark. Color development was stopped with $8 \mathrm{~N}$ $\mathrm{H}_{2} \mathrm{SO}_{4}$. The absorption was measured by ELISA plate reader at $490 \mathrm{~nm}$.

\section{Quantitative evaluation of PCR products with plate hybridization method}

M. leprae suspension containing $4.0 \times 10^{8} / \mathrm{ml}$ was diluted by ten fold serial dilution. Each diluted material, $2.5 \mu \mathrm{l}$, was added into the $22.5 \mu \mathrm{l}$ of PCR 
mixture containing $18 \mathrm{~F}$ and $18 \mathrm{R}$ primers. Quantity of target DNA sequence amplified from each template were analyzed by the staining with ethidium bromide after electrophoresis in $2 \%$ agarose gel. Concentration of DNA in each band at desired size were estimated by the correspondence with band, which showed same intensity of color as the sample, of $\Phi X 174 /$ HaelII molecular size marker applied $25 \mathrm{ng}$ per lane as usual. Same PCR products were diluted $1: 100,1: 1,000$, and $1: 10,000$, by the adsorbing buffer, and adsorbed and hybridized in micro-well plate. Serially diluted control DNA of known concentration, $0.04 \mathrm{ng} / 100 \mu \mathrm{l}$ to $16 \mathrm{ng} / 100$ $\mu l$, was also hybridized in the same plate and quantitative colorimetric determination was done under the same experimental condition. Only digoxigenin labeled probe was used due to the low sensitivity of biotin labeled probe. Original DNA concentration of PCR products was estimated by extrapolation. O. D. values obtained from the PCR products by the hybridization with digoxigenin labeled prove were plotted against a standard curve of control DNA according to extrapolation method. The DNA concentration were compared with both methods.

Table 1 : Estimation of PCR products

\begin{tabular}{ccc}
\hline $\begin{array}{c}\text { Eatimated } \\
\text { DNA Concentration } \\
\text { in Agarose Gel }\end{array}$ & $\begin{array}{c}\text { Template } \\
\text { Berillary Number }\end{array}$ & $\begin{array}{c}\text { Estimated } \\
\text { DNA Concentration by } \\
\text { Colorinetric Method }\end{array}$ \\
\hline & & \\
$2.53 \mathrm{ng} / \mathrm{ul}$ & $1.0 \times 10^{5}$ & $4.00 \mathrm{ug} / \mathrm{ul}$ \\
$1.75 \mathrm{ng} / \mathrm{ul}$ & $1.0 \times 10^{4}$ & $3.00 \mathrm{ug} / \mathrm{ul}$ \\
$1.60 \mathrm{ng} / \mathrm{ul}$ & $1.0 \times 10^{3}$ & $1.00 \mathrm{ug} / \mathrm{ul}$ \\
$0.89 \mathrm{ng} / \mathrm{ul}$ & $1.0 \times 10^{2}$ & $0.60 \mathrm{ug} / \mathrm{ul}$ \\
$0.67 \mathrm{ng} / \mathrm{ul}$ & $1.0 \times 10^{1}$ & $0.75 \mathrm{ug} / \mathrm{ul}$
\end{tabular}

\section{RESULTS}

\section{Sensitivity and specificity of the methods}

PCR amplified products by each primer pair $^{2,3,4,5)}$ were hybridized with probes against different PCR products each other, and no cross reactivity observed among them. Serial dilutions of probe were tested to detect the optimum concentra tion, and was found out to be approximate at 1 : 2,000 dilution. It was also confirmed that the probe did not hybridize with the primers contained in the sample.

Hybridization with digoxigenin and biotin gave different degree of sensitivity as shown in Figure 1. With digoxigenin, DNA concentration as low as $0.004 \mathrm{ng} /$ well gave a positive color development, therefore, the method could detect DNA at the level of picogram order. On the basis of these results, it was concluded that digoxigenin-11-dUTP was ten times the sensitivity of biotin.11-dUTP at least.

\section{Estimation of DNA amplified by PCR}

Quantitative estimation with agarose gel staining method on PCR products from serially diluted template material revealed proportional value with the original bacillary number and DNA concentra. tion as depicted in Figure 2. Agarose gel staining method gave almost negative result on the DNA of PCR product amplified from $1.0 \times 10^{1}$ bacilli. On the contrary, the plate hybridization method exhibited strong color development with same material. Hybridization technique with digoxigenin labeled probe was approximately 10,000 times the sensitivity of agarose gel staining method. Both procedures yielded proportional values with the original bacillary number as shown in Table 1 .

\section{DISCUSSION}

Though agarose gel electrophoresis followed by ethidium bromide staining is commonly employed for routine determination of PCR results $\left.{ }^{2} 3,4.5,6.7\right)$, the sensitivity of this method is low for a more objestive quantitative determination. DNA is detected with high sensitivity by the hybridization 


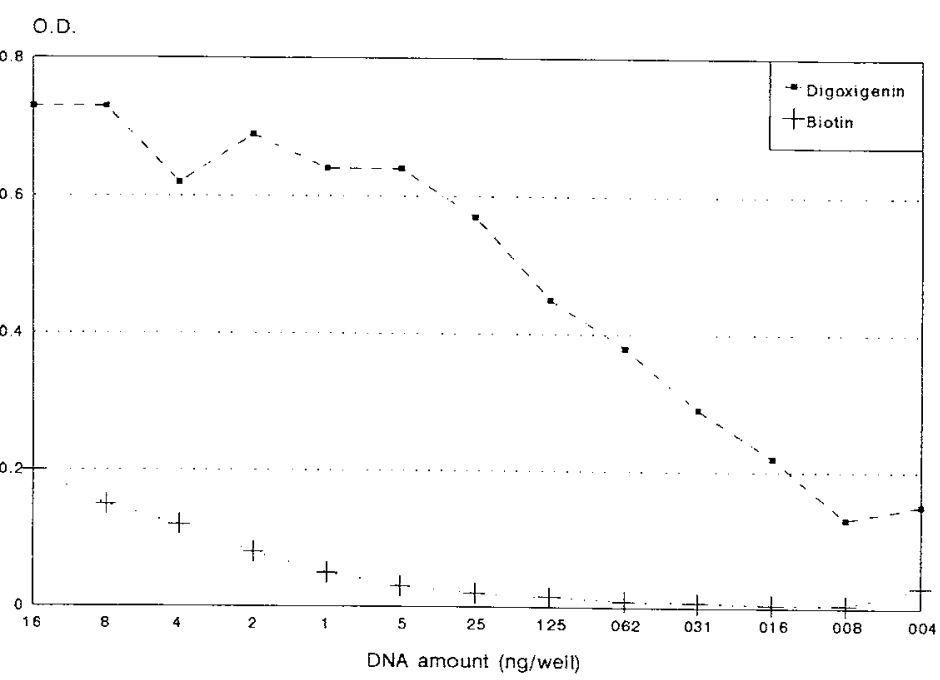

Fig. 1 : Hybridization with Digoxigenin and Biotin labeled probe

using with radioactive probe ${ }^{10\}}$, but it is not suitable for routine study of quantitative determina. tion. Inouye et al. had successfully determined the quantity of DNA amplified by PCR using with biotin probe in the micro-well of the plate ${ }^{8)}$. Aithough biotin was used more frequently than digoxigenin, it is generally said that digoxigenin labeled prove is more sensitive than the biotin labeled probe. Digoxigenin labeled prove was used in the southern hybridization to detect products of PCR successfully ${ }^{2)}$. Therefore, the utility of digoxigenin labeled probe in plate hybridization was examined.

In the preliminary experiments, the probe was adsorbed into the plate and intensity of color development was quite proportional to the amount of probe (data not shown). The results indicated that DNA was adsorbed efficiently to the well using the adsorbing buffer.

Hybridization with digoxigen in labeled prove was far more sensitive than with biotin labeled probe. The low efficacy of intake of biotin during probe preparation, or the low binding capacity of biotin to streptavidin was suspected as a contributing factor for the low degree of sensitivity of biotin labeled probe compared with that of digoxigenin labeled probe. Inouye et al. claimed that the DNA was quantified at the level of picogram order by the hybridization with biotin labeled probe and subse- quent detection by fluorescent method ${ }^{8)}$. They also mentioned that the detection method of hybridized biotin by means of streptavidin-conjugated peroxidase exhibited less sensitive than fluorescent method. In this study, peroxidase conjugated antidigoxigenin antibody were employed to detect digoxigenin in hybridized probe and color development was measured by ordinary micro-plate ELISA reader. Minimal detectable DNA amount by the method was at picogram order and same as Inouye's method, although fluorometric method is ten times high in sensitivity compare with the color development method by oxidation of substrate. The possibility was expected that DNA detection by digoxigenin labeled probe and fluorescent labeled anti-digoxigenin antibodies might be more sensitive than other non radioactive hybridization methods. Although the results from agarose gel staining and digoxigenin hybridization are proportional to the original template DNA concentration, low levels of DNA, which are not detectable in agarose gel, yielded good color development in hybridization technique. As little as 1-5 ng of DNA can be detected by ethidium bromide staining method ${ }^{11)}$. Since minimal detectable amounts of DNA with this method is picogram order, the micro plate hybri dization technique preserve the better sensitivity than staining method by far. 


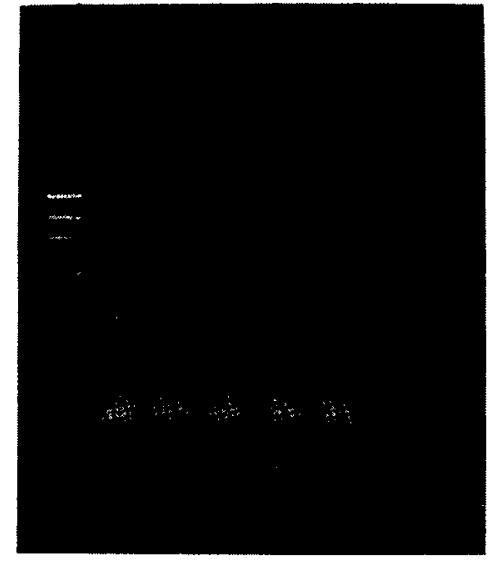

$\begin{array}{llllll}1 & 2 & 3 & 4 & 5 & 6\end{array}$

Fig. 2: Amplification of Mycobacterium leprae DNA with $18 \mathrm{~F}$ and $18 \mathrm{R}$ primers. Lane $1, \phi \times 174 /$ Haell molecular size marker. Original templates are $1.0 \times 10^{5}$ bacilli in lane $2.1 .0 \times 10^{4}$ badilli in lane $3,1.0 \times 10^{3}$ bacilli in lane $4,1.0 \times$ $10^{2}$ bacilli in lane 5 , and $1.0 \times 10^{1}$ bacilli in lane 6 .

Aside from its proven sensitivity and specificity, free primers and dNTP's are not hybridized with probes, since they are to short to be adsorbed to the plate $^{8)}$. It was also confirmed that they were not adhered to the plate in the preliminary study. Purification of the sample is not necessary. Plate hybridization method does not require long periods for washing, so the method is more convenient than hybridization on membrane. This method is more objective and safer than agarose gel staining, and many tests can be done simultaneously. With plate hybridization, it is possible to determine the quantity of unknown DNA concentration accurately. Diversity in results among experiments may be compensated by using control DNA. For the PCR studies to require a more accurate and precise quantitative determination of original and amplified DNA, micro-plate hybridization with digoxigenin 11-dUTP is strongly recommended.

\section{SUMMARY}

In this study, a new method was tried to estimate
PCR products of Mycobacterium leprae quantitatively by hybridization with non-isotope probe in microplate. Target DNA products were adsorbed into the well and hybridized with probe. The probes labeled with biotin or digoxigenin were prepared by PCR. Their sensitivities were compared. Digoxigenin was ten times high in sensitivity than biotin at least. No cross reactivity between other PCR products from M. leprae DNA and primers had been observed.

Reliability was evaluated by comparing the estimated quantity of PCR products between this method and the ethidium bromide stainined agarose gel method. Amplified products from different bacillary number of $M$. leprae were estimated by agarose gel electrophoresis. To estimate the concen tration of amplified DNA based on intensity of color development, the products were hybridized with digoxigenin labeled probe together with DNA of known concentration. The probes were detected by ELISA and O. D. values were plotted by extrapola. tion method. Both agarose gel staining and hybri dization procedures yielded proportional results with original bacillary number. The hybridization result was ten thousand times more sensitive than that of agarose gel staining method. Sensitivity of this method allows detection of PCR products at picogram level.

Plate hybridization method with digoxigenin labeled probe offers numerous advantages ; shorter washing period, safer than isotope probe and more objective than agarose gel electrophoresis, aside from its proven high degree of specificity and sensitivity. The potential application of this method for routine quantitative estimation of PCR products was indicated. It may be also said that original amount of template DNA corresponding to PCR product is estimated by this method.

\section{Acknowledgement}

This study was funded by a grant from the Sasakawa Memorial Health Foundation in part and scholarship from Japan International Cooperative Agency (JlCA). 


\section{REFERENCES}

1. Saiki, R. K. , Gelfand, D. H. , Stoffel, S., Scharf, S. J., Higuchi, R., Horn, G. T., K. B. Mullis, K. B. and Erlich. H. A. 1988. Primer-directed enzymatic amplification of DNA with a thermostable DNA polymerase. Science 239 : 487-491

2. Hartskeerl, R. A., De Wit, M. Y. L. and Klatser, P. R. 1989. Polymerase chain reaction for the detection of Mycobacterium leprae. J. Gen. Microbiol. 135 : 2357-2364

3. Woods, S. A. and Cole, S. T. 1989. A rapid method for the detection of potentially viable Mycobacterium leprae in human biopsies : a novel application of PCR. FEMS Microbiol. Lett. 65 : $305-310$

4. Plikaytis, B. B., Gelber, R. H. and Shinnick. T. M. 1990. Rapid and sensitive detection of Mycobacterium leprae using a nested-primer gene amplification assay. J. Clin. Microbiol. 28 : 1913-1917

5. Williams, D. L., Gillis, T. P., Booth, R. J. , Looker, D. and Watson, J. D. 1990. The use of specific DNA probe and polymerase chain reaction for the detection of Mycobacterium leprae. J. Infect. Dis. $162: 193-200$

6. de Wit, M. Y., Faber, W. R., Krieg, S. R. , Douglas, J. T., Lucas, S. B. , Montreewasuwat, N., Pattyn, S. R., Hussain R. , Ponnighaus, J. M. , Hartskeerl, R. A. 1991. Application of polymerase chain reaction for the detection of Mycobacterium leprae in skin tissues. J. Clin. Microbiol. 29 : 906-1011

7. Job C. K., Drain V., Williams D. L., Gillis T. P., Trauman R. W. Sanches R. M., Deming A. T. , and Hastings R. C. 1991. Comparison of polymerase chain reaction technique with other methods for detection of Mycobacterium leprae in tissues of wild nine-banded armadillos. Lepr. Rev. $62: 362-373$

8. Inouye, S. , and Hondo, R. 1990. Microplate hybridization of amplified viral DNA segment. J. Clin. Microbiol. 28 ; 1469-1472
9. Booth, R. J., Harris, D. P. . Love, J. M. and Watson, J. D. 1988. Antigenic proteins of Mycobacterium leprae. Complete sequence of the gene for the 18-Kda protein. J. Immunol. 8140 : 597-601

10. Williams, D. L., Gillis, T. P., Fialo, P., Job, C. K. , Gelber, R. H., Hill, C. and Izumi, S. 1992. Detection of Mycobacterium leprae and the potential for monitoring antileprosy drug therapy directly from skin biopsies by PCR. Mol. Cell. Prob. 6 : 401-410

11. Sambrook, J. Fritsch, E. F. and Maniatis, T. 1987. in Molecular Cloning, A Laboratory Manual, Second edition, Appendix E5, Cold Sping Harbor Laboratory Press, NY. 


\title{
此色法による PCR 増幅産物の定量
}

\author{
Jaime A. Dayanghirang ${ }^{1) 2)}$, 松 岡 正 典 $^{1)}$ \\ 1) 国立多摩䂰究所 \\ 2) Dr. Jose N. Rodriguez Memorial Hospital \\ キーワード：PCR, 定量, 非放射性プローブ, ELISA
}

PCRによって增幅された产:物を、䯩感度かつ齐 観的に検出，定星するための力江として，非放射 性プロープを用いた非出法の有用性が検討され た。

マイクロプレートウェルに一本鎖PCR增幅㢈物 を吸雇し，Digoxigenin（Dig.)をラベルしたプローブとハイブリダイゼーションを行なった後，パー オキシンダーゼ粡識抗 Dig 抗体によるELISAを 行なった。パーオキシダーゼ䌘職プローブは, Biotin 標識プローブより10倍以上の感度を示し， ピコグラム単位での検出, 定量が可能であった。
林知材料の定量は，既知材料の O. D. 储曲線に 刘して, ELESA の結果示されたO.D. 值を外捙子 ることにより求められた。この方法は同じく簡便 な方汒であるアガオースゲルによる定量に比し， 帘観性に優れ，10,000倍以上の感度を存し，アガ ロースゲルによる定量では，検出不能な低濃度材 料に刘しても有效であった。

本法は，他の筀是方法に比し，求放れる条件 即ち, 客観性, 感度, 手技の簡便性に優れ, PCR 産物の定量あるいはPCRによる堌楅の違いに 基づく Templetの推量に有用な手段であると結 論した。 